\title{
EFFECT OF ADDING SOME ORGANIC ANTIOXIDANTS TO BROILER DIETS UNDER HEAT STRESS CONDITIONS
}

\author{
A. Gouda ${ }^{1}$; M.M.A. El-Moniary ${ }^{1}$; E.F. Eldaly ${ }^{1}$; I. El-Wardany ${ }^{2}$ and A.A. Hemid ${ }^{2}$ \\ ${ }^{1}$ Animal production Dept., Agric. \& Biologic. Research Division, National Research Center, Dokki, Cairo, \\ Egypt. \\ ${ }^{2}$ Poultry. Production Dept., Fac. of Agric. Ain Shams Univ., Shoubra El- Kheima, Cairo, Egypt.
}

SUMMARY

\section{A} $\mathrm{n}$ experiment was conducted to investigate the effects of increasing dietary levels of organic chromium, organic selenium and Vitamin E on heat stressed broilers. A total of 120 1-d old commercial broiler chicks (Cobb) were obtained from a local hatchary. Upon arrival the chicks were divided into four groups with six replications, each of five chicks. The first group was the control group, while the second group was fed the basal diet supplemented with organic chromium $(0.8 \mathrm{mg} / \mathrm{kg}$ diet $)$, the third group was fed the basal diet supplemented with organic selenium $(0.3 \mathrm{mg} / \mathrm{kg}$ diet $)$ and the fourth group was fed the basal diet supplemented with vitamin E (200 IU/kg diet).Body weight (BW); body weight gain $(\mathrm{BWG})$; feed intake $(\mathrm{FI})$ and feed conversion ratio $(\mathrm{FC})$ were significantly $(\mathrm{P} \leq 0.05)$ improved in treatment groups compared to the control at 21 and 42 days of the age. Red blood cell count (RBSc), hematocrit (Ht), hemoglobin $(\mathrm{Hb})$, mean corpuscular hemoglobin $(\mathrm{MCH})$, mean corpuscular hemoglobin concentration (MCHC), mean corpuscular volume (MCV) and heterophils/lymphocytes ratios (H/l ratio) were significantly $(\mathrm{P} \leq 0.05)$ different in vitamin $\mathrm{E}$; organic selenium and organic chromium compared to the control at 21 and 42 days of the age, but RBSc count at 21 day of age were not significant. Moreover, values of glutathione peroxidase (GPX), Super-oxide dismutase (SOD) and Catalase (CAT) were significantly $(\mathrm{P} \leq 0.05)$ increased but Malondiadehyde (MDA) was significantly $(\mathrm{P} \leq 0.05)$ decreased with supplemental vitamin E; organic selenium and organic Chromium compared with control. Carcass characteristics of supplemented broilers were also improved $(\mathrm{P} \leq 0.05)$ compared to the control. However, abdominal fat, thymus, bursa and spleen were not significantly changed. The present results indicate that dietary supplementation of vitamin E; organic selenium and organic chromium, especially vitamin E, is necessary to overcome the deleterious effects of heat stress on broilers.

Key words: Broiler, antioxidant, heat stress, performance, hematology, enzyme, carcass.

\section{INTRODUCTION}

Homeostasis is constantly challenged by intrinsic and extrinsic stressors (Lin et al., 2006). Heat stress is of major concern for poultry industry, especially in the hot regions. The important traits governing productivity (growth performance, immune suppression and high mortality rate ..... etc) are adversely affected by heat stress (Mujahid et al., 2005, 2007 and Niu et al., 2009). When the temperature exceeds $30{ }^{\circ} \mathrm{C}$, signs of heat stress are likely to appear (Yardibi and Turkay, 2008). Biochemical and physiological events associated with hyperthermia can potentially promote reactive oxygen species formation which results in the disturbance of balance between the oxidation and anti oxidants defense systems, causing lipid peroxidation (LPO), in cell membranes, free radical peroxidation and oxidative injury in biological molecules, DNA and proteins. (Ando et al., 1997; Lin et al., 2006; Mujahid et al., 2006 and 2008 and Aslam et al., 2010). Furthermore, heat stress increases mineral and vitamin mobilization from tissues and their excretion, thus may exacerbate a marginal vitamin and mineral deficiency or an increased mineral and vitamin requirement. Several methods are available to alleviate the negative effects of heat stress, mostly focused on dietary manipulation. The major effects of heat stress are decreased feed intake and lower weight gain (El Moniary, 1991, Cahaner and Leenstra, 1992, El -Moniary et al., 1993 and Geraert et al., 1996). 


\section{Gouda et al.}

High temperature is enough to cause increased body temperature also change circulating leucocyte component in broilers and increased in $\mathrm{H} / \mathrm{L}$ ratio (Altan et al., 2000). Heat stress not only adversely affects production performance but also inhibits immune function (Mashaly et al., 2004).

Cells generate small amounts of free radicals or reactive oxygen species (ROS) during their normal metabolism, Mujahid et al. (2006) reported that acute heat stress resulted in increased levels of ROS in mitochondria. Excessive levels of ROS result in the disturbance of balance between the oxidation and antioxidant defense systems.

There is an abundance of literature on possible techniques to alleviate the adverse effects of heat stress in broiler chickens. One of the practical approaches that have yielded promising results is altering birds' abilities to cope with high ambient temperatures. Converging evidence suggests that stressful experiences during the neonatal stage can have considerable impact on various facets of an animal's physiology and behavior.

Dietary chromium supplementation has been reported to have a positive effect on growth rate and feed efficiency of growing poultry under stress conditions (Sahin et al. 2001 and Lien et al. 1999). Stress increases chromium mobilization from tissues and its excretion and also depresses in humans and animals including poultry (Borel et al. 1984 and Pardue et al. 1985). Selenium supplementation especially at 0.2 and $0.3 \mathrm{mg} / \mathrm{kg}$ diet significantly $(\mathrm{P} \leq 0.05)$ increased live body weight of chicks (ElSheikh et al. 2010 and Zhou and Wang 2011). In contrast, Patton et al. (2002) suggested that adding selenium yeast at $0.1,0.2$ or $0.3 \mathrm{ppm}$, was not significantly $(\mathrm{P}<0.05)$ affected feed intake. Similar results were observed by (Spears et al., 2003; Jiakui and Xiaolong 2004; Utterback et al 2005 and Ševčíková et al., 2006).

Vit.E were discovered and its role as an antioxidants was further characterized (Wolf, 2005). The Vit.E that is integrated into cellular membranes exerts its antioxidant effects by intercepting peroxyl radicals more rapidly than can polyunsaturated fatty acids (Burton and Traber, 1990). Lin et al. (2005) found that cockerels receiving supplements of more than $40 \mathrm{mg} / \mathrm{kg}$ vitamin $\mathrm{E}$ had higher body weight gain.

Therefore, the objective of the present study is to elucidate the effect of increasing dietary supplements levels of organic chromium, organic selenium and Vitamin E on growth performance, some antioxidants and heat acclimation markers, hematological parameters and the carcass characteristics of broilers under heat stress conditions. Finally, results from this study could provide a fundamental knowledge for using antioxidants to reduce oxidative stress and improve the productive performance and some physiological parameters in broiler production under hot climates of summer season in Egypt.

\section{MATERIALS AND METHODS}

A total of 1201 -d old commercial broiler chicks (Cobb) were obtained from a local hatchery. Upon arrival, the chicks were divided into four groups with six replications, each of five chicks. The first group was the control group, while the second group was fed the basal diet supplemented with 0.8 $\mathrm{mg} / \mathrm{kg}$ diet organic chromium, the third group was fed basal diet supplemented with $0.3 \mathrm{mg} / \mathrm{kg}$ diet organic selenium, the fourth group was fed basal diet supplemented with $200 \mathrm{IU} / \mathrm{kg}$ vitamin E. At 42-d of age all groups were exposed to $41 \pm 1^{\circ} \mathrm{C}$ for $1 \mathrm{~h}$.

The experimental diets and their calculated analysis are shown in Table (1). Feed and water were offered ad libitum and artificial light was provided for 23 hours daily all-over the experimental period, which lasted for 6 weeks. Chicks of the four treatments were kept under similar hygienic and environmental conditions and vaccinated against common diseases.

\section{Measurements:}

Chicks were weighed at 1, 21 and 42 days of age (DOA). Body weight (BW) was recorded to the nearest $0.1 \mathrm{~g}$. The average body weight gain (BWG) was calculated by subtracting the average of initial body weight of the birds in a certain stage from the final one in the same stage. Feed intake (FI) was 
recorded to the nearest $0.1 \mathrm{~g}$ and then the feed conversion ratio (FCR) was calculated as gram feed to gram body weight gain.

Table (1). Composition and calculated analysis of the experimental diets.

\begin{tabular}{|c|c|c|c|}
\hline Ingredient & $\begin{array}{c}\text { Starter } \% \\
1-21 \mathrm{D} \\
\end{array}$ & $\begin{array}{c}\text { Grower } \% \\
22-42 \mathrm{D} \\
\end{array}$ & $\begin{array}{l}\text { Vitamin and mineral mixture per } \mathrm{kg} \\
\text { of diet: }\end{array}$ \\
\hline Yellow corn & 55.35 & 60.45 & ach kilogram of diet contains:- \\
\hline Soybean meal (44\%) & 27.5 & 25 & VA, 12000 I.U., \\
\hline Corn gluten meal (62\%) & 8.9 & 6 & D3, 2500 I.U., \\
\hline Mono-Ca phosphate & 1.65 & 1.6 & E, 10mg., \\
\hline Limestone & 1.7 & 1.65 & B1, 2mg., \\
\hline Vegetable oil & 3.7 & 4.15 & B2, 5mg., \\
\hline Salt & 0.45 & 0.4 & B6, 4mg., \\
\hline Methionine & 0.15 & 0.15 & 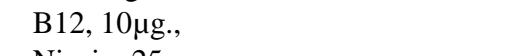 \\
\hline Lysine & 0.3 & 0.3 & Niacin, 25mg., \\
\hline Vitamin and mineral mixture & 0.3 & 0.3 & Pantothenic acid, 10mg., \\
\hline Total & 100 & 100 & 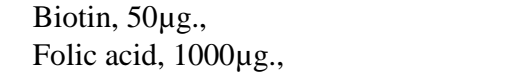 \\
\hline Calculated analysis & & & $\begin{array}{l}\text { Coline chloride, } 255 \mathrm{mg} \text {. } \\
\text { Selenium } 300 \mathrm{ug}\end{array}$ \\
\hline $\mathrm{ME} \mathrm{kcal/kg}$ & 3143 & 3190 & 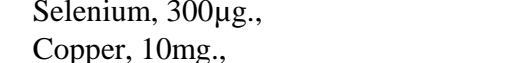 \\
\hline Crude protein $\%$ & 22.77 & 20.31 & Iodine, $1.0 \mathrm{mg}$., \\
\hline Lysine \% & 1.27 & 1.19 & $\mathrm{~K}, 2.0 \mathrm{mg}$ \\
\hline Methionine \% & 0.55 & 0.51 & Iron, 33mg., \\
\hline Methionine+ Cystine \% & 0.93 & 0.85 & Manganese, $60 \mathrm{mg}$. \\
\hline Calcium \% & 1.00 & 0.97 & Zinc, 60mg.. \\
\hline Av.Phosphorus \% & 0.47 & 0.47 & \\
\hline
\end{tabular}

Blood samples were collected from birds at 21 and 42 DOA during their exanguination into Waserman plastic tubes and Hemoglobin (Hb), hematocrit (HT), red blood cell count (RBSc), mean corpuscular hemoglobin $(\mathrm{MCH})$, mean corpuscular hemoglobin concentration (MCHC), mean corpuscular volume (MCV) and heterophils to lymphocytes ratios (H/l ratio).

Hemoglobin $(\mathrm{Hb})$ values as $\mathrm{g} / 100 \mathrm{ml}$. of whole blood were determined by cyanomethemoglobin method using commercial kit purchased from Spectrum Diagnostics Cairo, Egypt, as described by Tietz (1990). Red blood cell count (RBSc) were performed by the method described by Natt and Herrick (1952), The blood samples were pipetted in heparinized microhematocrite tubes, centrifuged at 3000 r.p.m for 15 minutes and the hematocrite (Ht) percent was recorded, mean corpuscular hemoglobin $(\mathrm{MCH})$, mean corpuscular hemoglobin concentration (MCHC), mean corpuscular volume (MCV), were calculated depended on Hb, RBSc and Ht. Blood smears were also done, stained with Wright's stain procedure and used to calculate the number of lymphocytes $(\mathrm{L})$ and heterophils $(\mathrm{H})$ in 100 white blood cells, and then the $\mathrm{H} / \mathrm{L}$ ratio was calculated.

After that the clotted blood was centrifuged at the speed of 4000 r.p.m for 15 minutes using laboratory centrifuge (SMIC, YJ03, Shanghahi, China). plasma were decanted into (1.5 ml) Ependorf tubes determine Glutathione peroxidase enzyme (GPX) activity in plasma was determined using commercial kit acording to according to Bell et al. (1986), superoxide dismutase (SOD) levels in plasma was measured by the method of Marklund and Marklund (1974), catalase (CAT) activity was determined by the method of Cohen et al (1970) and Malondialdehyde (MDA) production was determined by the method described by Placer et al. (1966).

At the end of the experimental period (42 day of age), three birds from each treatment group were randomly taken, weighed and slaughtered. Feathers were manually removed and eviscerated, weights of carcass, thigh, breast, liver, heart, gizzard and abdominal fat were also recorded to the nearest 1 gram and thymus, bersa and spleen were weighted and recorded to the nearest 0.01 gram. 


\section{Gouda et al.}

Data were subjected to one way analysis of variance using the General Linear Model procedures (SAS Institute 1996), Differences among means were detected by using Duncan,s multiple range test (Duncan, 1955).

\section{RESULTS AND DISCUSSION}

\section{1- Productive performance.}

Effect of different treatments on BW, BWG, FI and FCR traits of broilers chickens were illustrated in Table (2), It is appeared that $\mathrm{BW}$ at 21 and 42 day of age were significantly increased $(\mathrm{P}<0.05)$ from vitamin $\mathrm{E}$, organic selenium and organic chromium, respectively compared with control. A similar trend was also observed for BWG values at the same periods.

Table (2). Effect of dietary supplementation with organic chromium, organic selenium and Vitamin E on productive performance of broiler chicks at different ages.

\begin{tabular}{|c|c|c|c|c|c|c|}
\hline \multirow[b]{2}{*}{ Trait } & \multicolumn{4}{|c|}{ Treatment } & \multirow{2}{*}{ gnificance } & \\
\hline & Control & Chromium & ielenium & Vit. E & & \\
\hline B.W & 41.21 & 40.86 & 40.80 & 41.14 & NS & \\
\hline 1 D.O.A & \pm 0.617 & \pm 0.254 & \pm 0.488 & \pm 0.129 & & \\
\hline $\mathrm{BW}$ & $611.00^{c}$ & $633.33^{b c}$ & $550.00^{\mathrm{ab}}$ & $675.00^{\mathrm{a}}$ & $*$ & \\
\hline $21 \mathrm{DOA}$ & \pm 21.86 & \pm 25.81 & \pm 37.41 & \pm 35.07 & & \\
\hline BW & $1730.17^{b}$ & $1846.83^{\mathrm{a}}$ & $867.50^{\mathrm{a}}$ & $1885.67^{\mathrm{a}}$ & $*$ & \\
\hline $42 \mathrm{DOA}$ & \pm 62.05 & \pm 22.67 & \pm 59.11 & \pm 57.97 & & \\
\hline BWG & $569.79^{c}$ & $592.48^{b c}$ & ${ }_{09.20^{\mathrm{ab}}}$ & $633.86^{\mathrm{a}}$ & $*$ & \\
\hline $1-21$ & \pm 21.34 & \pm 25.57 & \pm 36.97 & \pm 34.95 & & \\
\hline BWG & $1119.17^{b}$ & $1213.50^{\mathrm{a}}$ & $217.50^{\mathrm{a}}$ & $1210.67^{\mathrm{a}}$ & $*$ & \\
\hline $21-42$ & \pm 42.50 & \pm 9.13 & \pm 26.21 & \pm 43.39 & & \\
\hline BWG & $1688.96^{b}$ & $1805.98^{\mathrm{a}}$ & $826.70^{\mathrm{a}}$ & $1844.52^{\mathrm{a}}$ & $*$ & \\
\hline $1-42$ & \pm 61.46 & \pm 22.43 & \pm 58.65 & \pm 57.87 & & \\
\hline FI & $794.33^{c}$ & $814.33^{b}$ & $320.16^{b}$ & $833.50^{\mathrm{a}}$ & $*$ & \\
\hline 1.21 & \pm 12.14 & \pm 5.24 & \pm 8.06 & \pm 3.39 & & \\
\hline FI & $2553.50^{b}$ & $2586.33^{\mathrm{ab}}$ & $580.83^{\mathrm{ab}}$ & $2615.50^{\mathrm{a}}$ & $* *$ & \\
\hline $21-42$ & \pm 1.04 & \pm 1.21 & \pm 4.83 & \pm 82.01 & & \\
\hline FI & $3347.83^{b}$ & $3400.67^{\mathrm{ab}}$ & $401.00^{\mathrm{ab}}$ & $3449.00^{\mathrm{a}}$ & $*$ & \\
\hline 1.42 & \pm 13.13 & \pm 6.15 & \pm 12.83 & \pm 84.62 & & \\
\hline FCR & 1.315 & 1.350 & 1.376 & 1.395 & NS & \\
\hline $1-21$ & \pm 0.032 & \pm 0.052 & \pm 0.072 & \pm 0.069 & & \\
\hline FCR & $2.28^{\mathrm{a}}$ & $2.13^{b}$ & $2.12^{b}$ & $2.16^{b}$ & & $*$ \\
\hline $21-42$ & \pm 0.087 & \pm 0.016 & \pm 0.041 & \pm 0.047 & & \\
\hline FCR & $1.98^{\mathrm{a}}$ & $1.88^{\mathrm{b}}$ & $1.86^{\mathrm{b}}$ & $1.87^{\mathrm{b}}$ & & $*$ \\
\hline $1-42$ & \pm 0.065 & \pm 0.020 & \pm 0.053 & \pm 0.016 & & \\
\hline
\end{tabular}

It is generally observed that, feed intake was significantly $(\mathrm{P}<0.05)$ increased in treatments of vitamin $\mathrm{E}$, organic selenium and organic chromium compared with control at periods from 1 to 21,21 to 42 and 1 to 42 days of age. Significant improvements were obtained in the feed conversion ratios at 21 to 42 and 1 to 42 days of age, but not at 1 to 21 days.

It is suggested that supplemental treatments could improve heat tolerance and alleviate performance reduction associated with stress conditions. These findings are in agreement with those reported by Sahin and Kucuk (2001) who indicated that the synthesis of vitamin E is reduced during heat stress, because of its anti-stress effects on body weight and feed intake during heat stress. Also, Ferket and Qureshi (1992) showed that supplementation of vitamin E on broilers diets submitted to heat stress improved weight gain 
and feed conversion ratio. Hegazy and Adachi (2000) observed a significant improvement in weight gain and feed conversion ratio of birds that were fed dietary supplementation of organic Se. Significant influences on body weight and feed intake by dietary supplementation of organic Se (Edens 2001; Spears et al., 2003 and Niu et al., 2009). Moreover, a linear increase in feed intake and improvement in feed efficiency was found in Se-supplemented birds reared under heat stress conditions. (Sahin et al. 2008; Chun et al., 2009; Attia et al., 2010 ; Zhou and Wang 2011; and Yang et al., 2012 ).

It is hypothesized that supplementation of $\mathrm{Cr}$ to the diet improves nutrient utilization such as carbohydrates and proteins by the role of $\mathrm{Cr}$ in increasing the sensitiveness of insulin receptors to insulin hormone and consequently increases the absorption of glucose by cells and considering that trivalent $\mathrm{Cr}$ is needed for proper metabolism of glucose in the body and the amount of $\mathrm{Cr}$ affects the ability of insulin in maintaining blood sugar levels (NRC, 1997). Therefore, by increasing levels of chromium in the diet, the metabolism of nutrients, including carbohydrates completely done and insulin hormone can also maintain blood sugar at longer time intervals, the chromium role in improving amino acid uptake by tissues and muscle cells and increases in protein retention in the body, this finding are illustrated in the improvement of BW, BWG, FI and FCR by organic Cr supplementation which is in agreement with Lien et al. (1999); Contreras et al. (2000); Gursoy, (2000) and Sahin et al. (2002; 2005) .

\section{2- Hematological parameters.}

Data presented in Table (3) clarify the effect of supplements of organic chromium, organic selenium and Vitamin E on red blood cell count (RBSc), hematocrit (HT), hemoglobin ( $\mathrm{Hb})$, mean corpuscular hemoglobin $(\mathrm{MCH})$, mean corpuscular hemoglobin concentration (MCHC), mean corpuscular volume

Table (3). Effect of dietary supplementation with organic chromium, organic selenium and Vitamin E on Hematological parameters of broiler chicks at different ages.

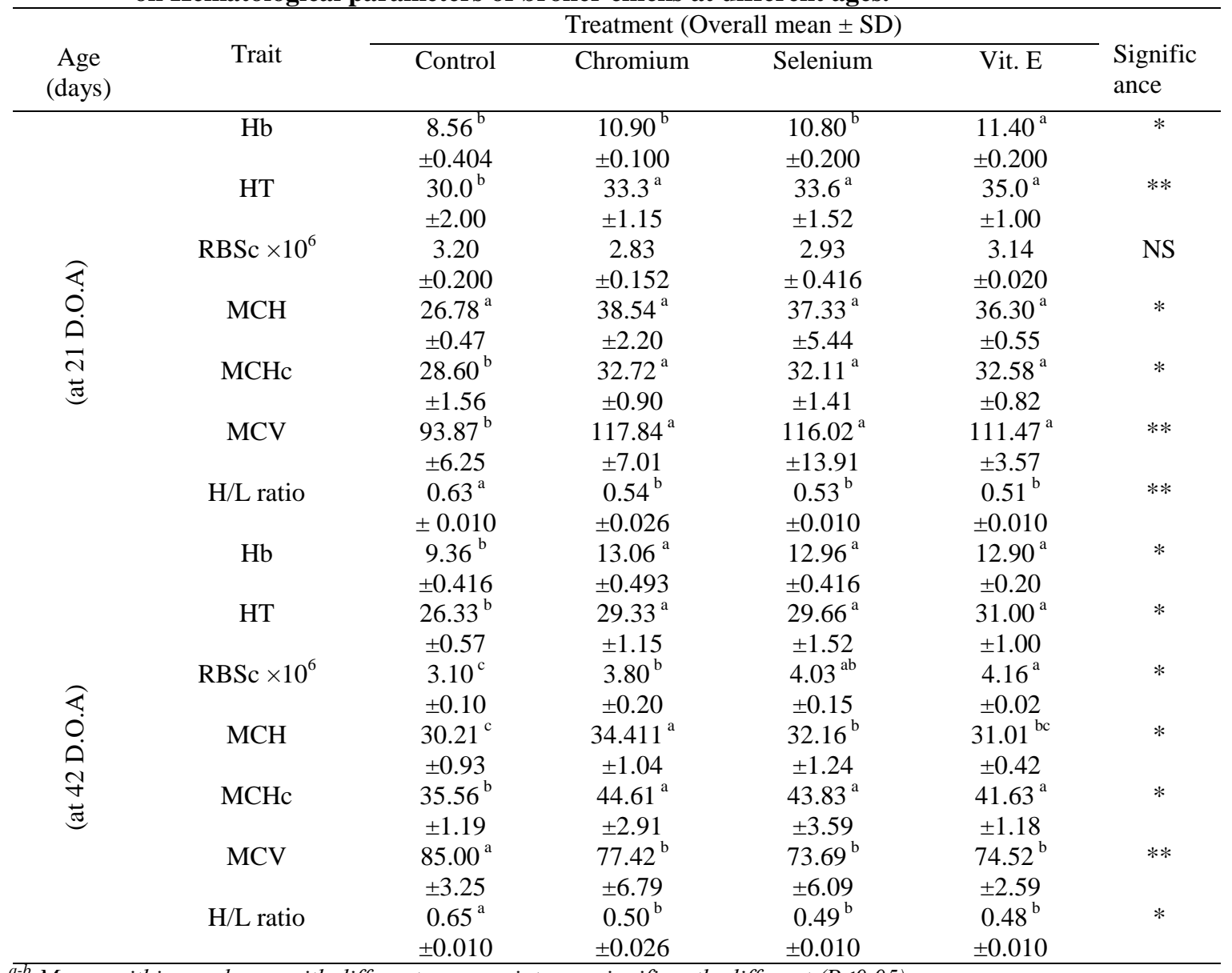

${ }^{a-b}$ Means within a column with different superscripts are significantly different $(P \leq 0.05)$.

$N S=$ non-significant, $*=P \leq 0.05 ; * *=P \leq 0.01$ 
(MCV) and heterophils lymphocytes ratios $(\mathrm{H} / 1$ ratio). The present data showed that significant $(\mathrm{p}<0.05)$ improvements in the hematological parameters were studied by the supplemented diets than the control. However, the RBSc counts at 21 day of age were not significant. Free radicals and peroxides play a significant role in physiological phenomena and in the pathogenesis of various diseases and are thought to participate in ageing, damaging oxidative tissues and increasing stress (Guemouri et al., 1991). The biological effects of these highly reactive substances are controlled in vivo by an endogenous antioxidant system, consisting of vitamin E and selenium, which improvement the blood parameter. Vitamin E works to protect phospholipids of cellular membranes and sub cellular, by preventing the oxidation of fatty acids with unsaturated bonds. These antioxidant effects of vitamin $\mathrm{E}$ in efficient high concentrations of oxygen and therefore is concentrated in red blood cells and membranes Dowd and Zheng (1995) and Muller (2010). Our results are in accordance with Shlig (2009) obtained his results from selenium and Vitamin E. Determination of some blood parameters has a substantial merit in understanding metabolic changes in heat-stressed poultry fed with dietary vitamin $\mathrm{E}$ and selenium. The results from the present study show that, hemoglobin increased significantly and hematocrit tended to increase in broilers fed supplemental Cr. Wilson (1971) reported that hematology may be used to diagnose both quantitative and morphologic physiological alterations that might be associated to heat stress, such as changes in hematocrit and hemoglobin. According to Kubena et al. (1972) exposure of chickens to high temperatures causes a decrease in blood hematocrit and hemoglobin values. Toghyani et al; (2006) reported that $\mathrm{Cr}$ supplementation increased hematocrit of stressed broiler. Research on $\mathrm{Cr}$ and its hematological effect in broiler are very limited.

\section{3- Antioxidant Status.}

Results in Table $(4)$ showed that significantly $(\mathrm{p}<0.05)$ higher activities of Glutathione peroxidase (GPX), superoxide dismutase (SOD) and catalase (CAT) enzymes at 42 DOA from vitamin E, organic selenium and organic chromium compared with control. However, all supplemented groups showed significantly $(\mathrm{p}<0.05)$ lowered malondialdehyde (MDA) level than control at the same age. Glutathione peroxidase GPX activity was highest in Se-fed broilers (Mahmoud and Edens, 2003). Edens et al (2001) reported that Se-fed broilers catalyzed a more rapid oxidation of GSH to GSSH because of higher glutathione peroxidase activity, These effects were similar to the present study. The results of increasing glutathione peroxidase activity in plasma by organic Se are in agreement with Jiang et al. (2009) who reported that the addition of $0.15 \mathrm{mg} / \mathrm{kg}$ or $0.225 \mathrm{mg} / \mathrm{kg}$ Se-Met significantly elevated GPX activities in broiler. Also, previous work has also shown that Se supplementation increases the activity of GPX in the tissues (Surai, 2000), which in close agreement with our results. It is well documented that, selenium is an important component of the antioxidant enzyme GPx and its actively involved in the antioxidant defense systems (Chantiratikul et al., 2011). Selenium is an essential component of Se-dependent glutathione peroxidase enzyme, which reduces peroxide and protects cells against the damaging effects of oxidation (Reddy et al., 2009). Dietary Se supplementation increased the plasma GPx activity in the broiler chickens (Jianhua et al. 2000, and Payne and Southern 2005). Khajali et al. (2010) found that the inclusion of organic Se source (selenomethionine) significantly elevated plasma GPx activity when measured at 42 days of bird's age, which can be regarded as an improvement of antioxidant status. In addition to the role of Se, as an antioxidant, methionine moiety can be converted to cysteine which in turn, converts to GSH. Both cysteine and GSH can function as direct scavengers of reactive oxygen species (ROS). GSH and cysteine can also protects proteins from irreversible oxidative damage through interactions between these thiols and proteins and the formation of mixed disulfides, such as glutathiolated protein (Mallis et al., 2002). Organic Selenium is actively absorbed by the same transport pathways as methionine and later incorporated (non-specifically) into tissues in place of methionine (Wolffram, 1999). Vitamin E functions as the primary chain-breaking antioxidant in the avian body, by scavenging free radicals and inhibiting the propagation of lipid oxidation (Jensen et al., 1995; Surai, 2006). Selenium plays an integral supportive role to Vit.E as a component of several glutathione peroxidases (GSH-Px), which are responsible for the cellular removal of the precursors of free radicals (i.e., hydro- peroxides) (Surai, 2006; Puvača and Stanaćev, 2011). In addition, Se is involved in the recycling of Vit.E through the seleno-enzyme thioredoxin reductase, which recycles ascorbic acid and, in turn, promotes the recycling of Vit.E (Surai, 2002; Surai, 2006; Skrrivan et al., 2008). In fact, it has been shown that the action of these Se-dependent enzymes often display a "sparing" effect on the Vit.E stores in poultry by reducing the demand on Vit.E for the inhibition of lipid peroxidation, ultimately rendering more Vit.E available to the animal (Surai, 2000; Surai, 2006; Skřivan et al., 2008). The results of SOD activity is in accordance with the earlier reports (Eid et al., 2008 and Sujatha et al., 2010), they found significant increase in SOD activities of vitamin E supplemented groups. It is suggested that antioxidant vitamin E supplementation during heat stress enhances SOD activity to minimize oxidative stress in chicken by inhibiting the oxygen free radical production and scavenging the superoxide ions (Ozturk-urek, et al., 2001). 
As the stress period increased the enzyme activity in control, upward trend was observed in all supplemented groups. The result also clearly explains the synergistic effect of vitamin E (Sahin et al., 2002 and 2003). Combination with vitamin E and organic selenium increasing SOD activities, this result are confirms the findings of (Hill , 1992; Ogo et al. 1996; and Tras et al., 2000). In the cell, catalase reacts with generated hydrogen peroxide to form water and molecular oxygen thereby protecting the cells against hydrogen peroxide toxicity and lipid peroxidation Yamaguchy 1991. Erythrocyte CAT levels in the vitamin E supplemented groups under heat stress demonstrated an increasing trend, as compared to the control group, might be due to synergistic effect of vitamin $\mathrm{E}$ on scavenging free radicals and hydrogen peroxides, that is well supported by the findings of others (Panda et al., 2007; Eid et al., 2008 and Yardibi and Turkay et al., 2008). As environmental temperature increases respiration and evaporation increases to maintain optimal body temperature, which in turn increases their metabolism and energy consumption. If increased energy needs is not supplied with feed (less feed consumption during heat stress), mobilization of lipids from stored fat takes place. The MDA level, an indicator of lipid per-oxidation, increases with increases in lipid mobilization and oxidation of lipids. Level of erythrocyte MDA continued to rise in hens exposed to heat stress (control) and hens fed rations containing vitamin E separately or their combinations showed significantly lower MDA level. Feeding of the antioxidant vitamins for during summer stress decreased the MDA concentration from its level recorded at one month. This result is in accordance with the earlier findings (Puthpongsiriporn et al., 2001; Panda et al., 2007; Sahin et al., 2002 and Lin et al., 2005). The observed decrease in erythrocyte MDA levels in the groups supplemented with vitamin $\mathrm{E}$ and their combinations might have been due to the inhibition of lipid peroxidation in erythrocyte membranes due to the antioxidant effect of vitamin E. This study suggests that lipid peroxides formed under heat stress conditions can be partially counteracted by dietary inclusion of antioxidants such as vitamin E. It is well known that Cr plays an important role as integral component of the Glucose Tolerance Factor (GTF), which potentate the action of insulin and regulate fat metabolism Mertz (1993). It has been well recognized that insulin metabolism influences lipid per-oxidation (Gallaher, et al., 1993). $\mathrm{Cr}$ is insulin cofactor, therefore postulated to function as an antioxidant (Preuss, et al., 1997). According to antioxidant theory of Klasing (1993), the concentrations of antioxidant decrease when the lipid per-oxidation increases in the plasma and tissues, leading to damage of cell membranes. Sahin et al. (2003) reported supplemental $\mathrm{Cr}$ resulted in decrease MDA in serum concentrations of heat-stressed broiler chicks, they added, when Japanes quails were fed by $\mathrm{Cr}$, MDA concentration in serum decreased.

Table (4). Effect of dietary supplementation with organic chromium, organic selenium and Vitamin $E$ on Antioxidant Status at 42 day of age.

\begin{tabular}{|c|c|c|c|c|c|}
\hline \multirow[b]{2}{*}{ Trait } & \multicolumn{4}{|c|}{ Treatment } & \multirow[b]{2}{*}{ Significance } \\
\hline & Control & Chromium & Selenium & Vit. E & \\
\hline GPX & $3.86^{\mathrm{c}}$ & $8.07^{b}$ & $9.38^{\mathrm{a}}$ & $9.44^{\mathrm{a}}$ & \\
\hline$(\mathrm{U} / \mathrm{ml})$ & \pm 0.29 & \pm 0.06 & \pm 0.56 & \pm 0.66 & $*$ \\
\hline SOD & $1.75^{\mathrm{c}}$ & $2.63^{b}$ & $3.04^{\mathrm{a}}$ & $3.03^{\mathrm{a}}$ & \\
\hline$(\mathrm{U} / \mathrm{ml})$ & \pm 0.07 & \pm 0.10 & \pm 0.21 & \pm 0.13 & $*$ \\
\hline CAT & $24.64^{\mathrm{d}}$ & $26.82^{\mathrm{c}}$ & $34.04^{\mathrm{a}}$ & $30.30^{\mathrm{b}}$ & \\
\hline$(\mathrm{U} / \mathrm{ml})$ & \pm 0.13 & \pm 0.09 & \pm 0.73 & \pm 1.48 & $*$ \\
\hline MDA & $5.92^{\mathrm{a}}$ & $4.93^{b}$ & $4.10^{c}$ & $4.13^{c}$ & \\
\hline$(\mathrm{nmol} / \mathrm{ml})$ & \pm 0.35 & \pm 0.44 & \pm 0.02 & \pm 0.01 & $*$ \\
\hline
\end{tabular}

\section{3- Carcass characteristics and some organs.}

The overall means of carcass weight $(\%)$ and the proportional weights of some body organs are presented in Table (5) it was illustrated that at marketing age (42 DOA), dressing carcass weight, breast, thigh, gizzard and heart as a percentage of live body weight were markedly significantly $(\mathrm{P} \leq 0.05)$ higher for birds fed diets supplemented with vitamin E, organic selenium and organic chromium, compared with control. Conversely, the relative weights of liver were significantly $(\mathrm{P}<0.05)$ decrease for all treatment compared with control. On the other hand, the relative weights of abdominal fats, thymus, bursa and spleen were not significantly affected.

These results may support the previous findings that broilers are able to compensate the retardation of growth by different magnitudes including the well documented relationships between the dietary 


\section{Gouda et al.}

supplements and some endocrine functions which include the stimulatory effects of vit.E and organic Se on thyroid gland activity under heat stress conditions. It is well known that the normal growth of all body organs needs a euthyroid status. In accordance with the results of the performance data of the present study, it has been suggested that thyroid activity is affected by environmental temperature which made a linear correlation between plasma $\mathrm{T}_{3}$ concentration, feed intake and weight gain to a good improvement in carcass characteristics by increasing its weights (McNabb and King., 1993; Yahav et al., 1997; Yahav 1999 and Sahin et al., 2002).

Table (5). Effect of dietary supplementation with organic chromium, organic selenium and Vitamin E on Carcass characteristics and some organs of broiler chicks.

\begin{tabular}{|c|c|c|c|c|c|}
\hline \multirow{2}{*}{$\begin{array}{c}\text { Trait } \\
(\%)\end{array}$} & \multicolumn{4}{|c|}{ Treatment } & \multirow[b]{2}{*}{ Significance } \\
\hline & Control & Chromium & Selenium & Vit. E & \\
\hline \multirow[t]{2}{*}{ Caracas } & $66.17^{\mathrm{c}}$ & $68.94^{b}$ & $70.87^{\mathrm{a}}$ & $69.77^{\mathrm{ab}}$ & \\
\hline & \pm 0.493 & \pm 0.519 & \pm 1.050 & \pm 0.404 & $*$ \\
\hline \multirow[t]{2}{*}{ Breast } & $14.93^{b}$ & $15.60^{\mathrm{ab}}$ & $15.97^{\mathrm{a}}$ & $15.88^{\mathrm{a}}$ & \\
\hline & \pm 0.904 & \pm 0.163 & \pm 0.152 & \pm 0.224 & $*$ \\
\hline \multirow[t]{2}{*}{ Thigh } & $11.60^{\mathrm{b}}$ & $12.40^{\mathrm{ab}}$ & $12.91^{\mathrm{a}}$ & $12.84^{\mathrm{a}}$ & \\
\hline & \pm 0.904 & \pm 0.190 & \pm 0.556 & \pm 0.550 & $*$ \\
\hline \multirow[t]{2}{*}{ Liver } & $2.08^{\mathrm{a}}$ & $1.85^{\mathrm{b}}$ & $1.83^{\mathrm{b}}$ & $1.86^{\mathrm{b}}$ & \\
\hline & \pm 0.041 & \pm 0.060 & \pm 0.045 & \pm 0.092 & $*$ \\
\hline \multirow[t]{2}{*}{ Gizzard } & $1.10^{\mathrm{b}}$ & $1.15^{\mathrm{a}}$ & $1.16^{\mathrm{a}}$ & $1.17^{\mathrm{a}}$ & \\
\hline & \pm 0.015 & \pm 0.037 & \pm 0.025 & \pm 0.015 & $*$ \\
\hline \multirow[t]{2}{*}{ Heart } & $0.34^{\mathrm{b}}$ & $0.40^{\mathrm{a}}$ & $0.42^{\mathrm{a}}$ & $0.43^{\mathrm{a}}$ & \\
\hline & \pm 0.026 & \pm 0.015 & \pm 0.011 & \pm 0.030 & $*$ \\
\hline \multirow[t]{2}{*}{ A.F } & 1.13 & 1.16 & 1.18 & 1.20 & \\
\hline & \pm 0.011 & \pm 0.010 & \pm 0.026 & \pm 0.106 & NS \\
\hline \multirow[t]{2}{*}{ Thymus } & 0.23 & 0.25 & 0.24 & 0.24 & \\
\hline & \pm 0.015 & \pm 0.017 & \pm 0.015 & \pm 0.005 & NS \\
\hline \multirow[t]{2}{*}{ Bursa } & 0.14 & 0.13 & 0.13 & 0.12 & \\
\hline & \pm 0.035 & \pm 0.051 & \pm 0.020 & \pm 0.011 & NS \\
\hline \multirow[t]{2}{*}{ Spleen } & 0.23 & 0.22 & 0.21 & 0.22 & \\
\hline & \pm 0.020 & \pm 0.015 & \pm 0.005 & \pm 0.005 & NS \\
\hline
\end{tabular}

${ }^{a, b, c}$ Means $\pm S D$ within a row with different superscripts are significantly different $(P \leq 0.05)$.

$N S=$ non-significant,$*=P \leq 0.05 . \quad$ A.F $=$ abdominal fat $(\%)$

In this study, the non-significant effect of $\mathrm{Cr}$ supplementation on abdominal fat is in agreement with those of Lien et al. (1999), but is in incoherence with those of Ward et al. (1993), Hossain et al. (1998) and Sahin et al. (2003).

\section{REFERENCES}

Altan, O.; A. Altan; I. Oguz; A. Pabuccuolu and S. Konyaliouglu (2000). Effects of heat stress on growth, some blood variables and lipid oxidation in broilers exposed to high temperature at an early age. $\mathrm{Br}$. Poult. Sci., 41: 489- 493.

Ando, M.; Katagiri, K.; Yamamoto, S.; Wakamatsu, K.; Kawahara, I.; Asanuma, S.; Usuda, M. and Sasaki, K. (1997). Age-related effects of heat stress on productive enzymes for peroxides and microsomal monooxygenase in rat liver. Environ. Health Perspect. 105, 726-733.

Aslam, F.; Khan, M. Z.; Khan, S.; Sharaf, S. T.; Gulang, M. K. and Saleemi M. K. (2010): toxicopathological changes induced by cypermethrin in broiler chicks: their attenuation with Vitamin $\mathrm{E}$ and selenium. Experimental and Toxicologic, 62: 441-450.

Attia Y.A.; Abdalah, A.A.; Zeweil, H.S.; Bovera, F.; Tag El-Din, A.A. and Araft, M.A. (2010). Effect of inorganic or organic selenium supplementation on productive performance, egg quality and some physiological traits of dual-purpose breeding hens. Czech J. Anim. Sci., 55, (11): 505-519 
Bell, J.G., Pirie, B.J.S., Adron, J.W., Cowey, C.B., 1986. Some effect of selenium deficiency on glutathione peroxidase (EC 1.11.1.9) activity and tissue pathology in rainbow trout (Salmo gairdneri). Br. J. Nutr. 55, 305-311.

Borel, J.S., T.C. Majerus, M. Polansky, P.B. Moser and R.A. Anderson, 1984. Chromium intake, and urinary chromium excretion of trauma patients. Biol. TraceElement Res., 6: 317-325.

Burton, G. M. and M. G. Traber. 1990. Vitamin E: Antioxidant activity, biokinetics, and bioavailability. Annu. Rev. Nutr. 10:357-382.

Cahaner, A. and F. Leenstra (1992). Effect of high temperature on growth and efficiency of male and female broilers from lines selected for high weight gain, favorable feed conversion and high or low fat content. Poult. Sci., 71: 1237- 1250.

Chantiratikul, A.; Chinrasri, O.; Pakmaruek, P.; Chantiratikul, P.; Thosaikham, W. and Aengwanich, W. (2011) Responses of Growing Japanese Quails that Received Selenium from Selenium Enriched Kale Sprout (Brassica oleracea var. alboglabra L.). Biol Trace Elem Res 144:760-768.

Chun, F.; Bing, Y.; and Chen, D. (2009) Effects of Different Sources and Levels of Selenium on Performance, Thyroid Function and Antioxidant Status in Stressed Broiler Chickens. Int. J. Poult. Sci., 8 (6): 583-587.

Cohen, G., D. Dembiec and J. Marens, (1970). Measurement of Catalase Activity in Tissue Extracts, Analytical Bioche- mistry, Vol. 34, No. 1, pp. 30-38.

Contreras, G., N. Montesinos and R. Barajas, 2000. Effect of supplementation in drinking water with two organic chromium sources on blood glucose level and weight gain of Japanese quail (Coturnix coturnix japonica) in their first week of live. J. Anim. Sci., 78(Suppl. 1): 241.

Doumas, B. T., Warson, W.A. and Biggs, N.G. 1971. Albumin standards and the measurement of serum albumin with bromcresol green. Clin. Chem. Acta., 31:87-96.

Dowd P, Zheng ZB (1995). On the mechanism of the anticlotting action of vitamin E quinone. Proc Natl Acad Sci U S A. 92 (18): 8171-8175.

Duncan, D. B. (1955). Multiple range and multiple F tests. Biometrics 11:1- 42.

Edens, F.W., 2001. Involvement of Sel-Plex in physisological stability and performance of broiler chickens. Pages 349- 376 in: Biotechnology in the feed industry. Proceedings of Alltech's 17th annual symposium. T.P. Lyons and K.A. Jacques (eds.), Nottingham University Press, Nottingham, U.K.

Edens, F.W., 2001. Involvement of Sel-Plex in physisological stability and performance of broiler chickens. Pages 349- 376 in: Biotechnology in the feed industry. Proceedings of Alltech's 17th annual symposium. T.P. Lyons and K.A. Jacques (eds.), Nottingham University Press, Nottingham, U.K.

Eid, Y. T. Ebeid, M. Moawad and M. El-Habbak, (2008). Re- duction of Dexamethasone-Induced Oxidative Stress and Lipid Peroxidation in Laying Hens by Dietary Vitamin E Supplementation. Emirates Journal of Food and Agri- culture, Vol. 20, No. 2, pp. 28-40.

El- Moniary, M. M. A. (1991). Studies on broiler feeding in the subtropics. Ph. D. Thesis, Ain shams University, Fac. Of Agric, Egypt.

El- Moniary, M. M. A.; M. Larbier; A. H. Abd El- Gawad; H. S. Soliman; H. M. Ali and H. A. El- Alily 1993. The influence of dietary energy density and different environmental temperature on (1) broiler performance. J. Agric. Sci. Mansoura Univ., 18(10): 2921- 2929.

El-Hommosany Y.M., 2008. Study of the Physiological Changes in Blood Chemistry, Humoral Immune Response and Performance of Quail Chicks Fed Supplemental Chromium. International Journal of Poultry Science 7 (1): 40-44.

El-Sheikh, A.M.H.; Abdella, E.A. and Hanafy, M.M. 2010. The effect of organic selenium supplementation on productive and physiological performance in a local strain of chicken.2- immune system and some physiological aspects in bandarah chicks affected by organic selenium. Egypt. Poult. Sci. Vol (30) (II): (517-533). 


\section{Gouda et al.}

Ferket PR, Qureshi MAA. 1992. Performance and immunity of heat-stressed broilers fed vitamin- and electrolyte supplemented drinking water. Poultry Science; 71(1):88-97.

Gallaher, D.D., Csallany, A.S., Shoeman, D.W., Olson, J.M., 1993. Diabetes increases excretion of urinary malondehyde conjugates in rats. Lipids 28, 663-666.

Geraert, P. A.; Padilha, J. C.; S. Guillaumin, (1996). Metabolic and endocrine changes induced by chronic heat exposure in broiler chickens: biological and endocrinological variables. Br. J. Nutr, 75, 205-216.

Guemouri, L., Artur, Y., Herbert, B., Jeandel, C., Cuny, G. \& Siest, G. (1991) Biological variability of superoxide dismutase, glutathione peroxidase and catalase in blood. Clinical Chemistry, 37: 1932-1937.

Gursoy, U., 2000. Chromium in broiler diets. Feed International, New York, pp: 24-26.

Hegazy S. M, Adachi Y. 2000. Comparison of the effects of dietary selenium, zinc and selenium and zinc supplementation on growth and immune response between chick groups that were inoculatedSalmonella and Aflatoxin or Salmonella. Poultry Science; 79:331-335.

Henry, R. J. 1974. Clinical Chemistry: Principles and Techniques. New York, NY: Harper and Row.

Hill, M.R. (1992) Porcine stress deaths. Veterinary Record, 130: 59.

Hossain, S. M.; S. L. Barreto; A. G. Bertechini; A. M. Rios, and C. G. Silva (1998). Influence of dietary vitamin $\mathrm{E}$ level on egg production of broiler breeders, and on the growth and immune response of progeny in comparison with the progeny from eggs injected with vitamin E. Anim. Feed Sci. Techol., 78:307-317.

Jensen, C., L. H. Skibsted, K. Jakobsen, and G. Bertelsen. (1995). Supplementation of broiler diets with allrac- $\alpha$ - oor a mixture of natural source RRR- $\alpha-, \gamma-, \delta$ - tocopherol acetate. 2 . Effect on the oxidative stability of raw and precooked broiler meat products. Poult. Sci. 74:2048-2056.

Jiakui, L. and Xiaolong, W. 2004. Effect of dietary organic versus inorganic selenium in laying hens on the productivity, selenium distribution in egg and selenium content in blood, liver and kidney. J Trace Elem Med Biol 18:65-68.

Jiang, Z.; Lin, Y.; Zhou, G.; Luo, L.; Jiang, S. and Chen, F. (2009). Effects of Dietary Selenomethionine Supplementation on Growth Performance, Meat Quality and Antioxidant Property in Yellow Broilers. J. Agric. Food Chem. 57, 9769-9772.

Jianhua H, Ohtsuka A and Hayashi K (2000). Selenium influences growth via thyroid hormone status in broiler chickens. British Journal of Nutrition, 84: 727-732.

Khajali F, Raei A, Aghaei A and Qujeq D (2010). Evaluation of a dietary organic selenium supplement at different dietary protein concentrations on growth performance, body composition, and antioxidative status of broilers reared under heat stress. Asian Australasian Journal of Animal Science, 23 (4): $501-507$.

Klasing, K.C., 1993. Comparative Avian Nutrition.University Press, Cambridge, pp. 277-299.

Kubena, L.F., J.D. May, F.N. Reece and J.W. Deaton, 1972. Hematocrit and hemoglobin levels of broilers as influenced by environmental temperature and dietary iron level. Poult. Sci., 51: 759-763.

Lien, T.F., Y.M. Horng and K.H. Yang, 1999. Performance, serum characteristics, carcass traits and lipid metabolism of broilers as affected by supplement of chromium picolinate. Br. Poult. Sci., 40: 357-363.

Lin, H.; Decuypere, E. and Buyse, J. (2006). Acute heat stress induces oxidative stress in broiler chickens. Comp. Biochem. Physiol. Part A 144, 11-17.

Lin, Y. F.; S. J. Chang; J. R. Yang; Y. P. Lee, and A. L. Hsu (2005). Effects of supplemental vitamin E during the mature period on the reproduction performance of Taiwan native chicken cockerels. Br. Poult. Sci., 46:366-73.

Lin, Y. F.; S. J. Chang; J. R. Yang; Y. P. Lee, and A. L. Hsu 2005. Effects of supplemental vitamin E during the mature period on the reproduction performance of Taiwan native chicken cockerels. Br. Poult. Sci., 46:366-73. 
Mahmoud, K.Z., Edens, F.W., 2003. Influence of selenium sources on age related and mild heat stressrelated changes of blood and liver glutathione redox cycle in broiler chickens (Gallus domesticus). Comp. Biochem. Physiol. B 137, 921-934.

Mallis RJ, Hamann MJ, Zhao W, Zhang T, Hendrich S and Thomas JA (2002). Irreversible thiol oxidation in carbonic anhydrase III: protection by S-glutathiolation and detection in aging rats. Biological Chemistry, 383: 649-662.

Marklund S. and G. Marklund, (1974) Involvement of Super- oxide Anion Radical in the Autooxidation of Pyrogallol and a Convenient Assay for SOD, European Journal of Biochemistry, Vol. 47, No. 3, pp. 464474.

Mashaly, M. M.; G. L. Hendricks; M. A. Kalama; A. E. Gehad; A.O. Abbas and P. H. Pattersont (2004). Effect of heat stress on production parameters and immune responses of commercial laying hens. Poult. Sci., 83: 889- 894.

McNabb, F. M. and D. B. king, (1993). Thyroid hormones effects on growth, development and metabolism. In "The endocrinology of growth development and metabolism in vertebrates, Eds. Schreibman, M., Scanes, C. and Pang, P. Academic press, USA.393 pp.

Mertz, W., 1993. Chromium in human nutrition: A review. J. Nutr., 123: 626-633.

Mujahid, A.; Akiba, Y. and Toyomizu, M. (2007). Acute heat stress induces oxidative stress and decreases adaptation in young white leghorn cockerels by down- regulation. Poult. Sci. 86, 364-371.

Mujahid, A.; Pumford, N. R.; Bottje, W.; Nakagawa, K.; Miyazawa, T.; Akiba, Y. and Toyomizu, M. (2008). Mitochondrial oxidative damage in chicken skeletal muscle induced by acute heat stress. J. Poult. Sci. 44, 439-445.

Mujahid, A.; Sato, K.; Akiba, Y. and Toyomizu, M. (2006). Acute heat stress stimu- lates mitochondrial superoxide production in broiler skeletal muscle, possibly via downregulation of uncoupling protein content. Poult. Sci. 85, 1259-1265.

Mujahid, A.; Y. Yoshiki; Y. Akiba and M. Toyomizu (2005). Superoxide radical production in chicken skeletal muscle induced by acute heat stress. Poultry Sci. 84(2):307-314.

Mujahid, A.; Yoshiki, Y.; Akiba, Y. and Toyomizu, M. (2005). Superoxide radical production in chicken skeletal muscle induced by acute heat stress. Poult. Sci. 84, 307-314.

Muller DP (2010). Vitamin E and neurological function. Review. Mol. Nutr. Food Res 54 (5): 710-718.

Natt, M. P; Herrick C. A. 1952 A new diluents for counting the Erythrocytes and leukocytes for chickens. Poult. Sic., 31:735-8.

Niu, Z. Y.; Liu, F. Z.; Yan, Q.L. and Li, W. C. (2009): effects of different levels of vitamin E on growth performance and immune responses of broilers under heat stress. Poult. Sci., 88: 2101-2107.

Niu, Z.Y.; Liu, F.Z.; Yan, Q.L.; Li, W.C. 2009. Effects of different levels of vitamin E on growth performance and immune responses of broilers under heat stress. Poult. Sci., 88, 2101-2107.

NRC, 1997. The Role of Chromium in Animal Nutrition. National Research Council, National Academy Press, Washington, DC.

Ogo, Y., Kasa, T. and Kiriyama, S. (1996) Vitamin E prevents the elevation of thiobarbituric acid reactive substances but not hemolytic anemia in rats fed excess methionine. Journal of Nutritional Biochemistry, 7: 77-84.

Ozturk-urek, R.; L. A. Bozkayaa and L. Tarhan, 2001. The Effect of Some Antioxidant Vitamin and Trace Element- Supplemented Diets on Activities of SOD, CAT, GSH-Px and LPO Levels in Chicken Tissues. Cell Biochemistry Function, Vol. 19, No. 2, pp. 125-132.

Panda A. K., S. V. Ramarao and M. V. L. N. Raju, 2007. Effect of Vitamin C Supplementation on Performance, Im- mune Response and Antioxidant Status of Heat Stressed White Leghron Layers. Indian Journal of Poultry Sci- ence, Vol. 42, No. 2, pp. 169-173.

Pardue SL, Thaxton JP, Brake J. 1985; Influence of supplemental ascorbic acid on broiler performance following exposure to high environmental temperature. Poult Sci 64:1334-8. 


\section{Gouda et al.}

Patton, N. D.; Cantor, A.H.; Pescatore, A.J.; Ford, M.J. and Smith, C.A. 2002. The effect of dietary selenium source and level on the uptake of selenium by developing chick embryos. Poult. Sci. 81, 1548- 1554.

Payne RL and Southern L. L., 2005. Changes in glutathione peroxidase and tissue selenium concentrations of broilers after consuming a diet adequate in selenium. Poultry Science, 84: 1268-1276.

Placer, Z. A., L. Cushman and B. Johnson, (1966) Estimation of Products of Lipid Peroxidation (MDA) in Biochemical System, Analytical Biochemistry, Vol. 16, No. 2, pp. 359-364.

Preuss, H.G., Grojec, P.L., Lieberman, S., Anderson, R.A., 1997. Effects of different chromium compounds on blood pressure and lipid peroxidation in spontaneously hypertensive rats. Clin. Nephrol. 47, 325-330.

Puthpongsiriporn, U., S. E. Scheideler, J. L. Sell and M. M. Beck, 2001. Effects of Vitamin E and C Supplementation on Performance, in Vitro Lymphocyte Proliferation, and Antioxidant Status of Laying Hens During Heat Stress. Poultry Science, Vol. 80, No. 8, pp. 1190-1200.

Puvača, N., and V. Stanaćev. 2011. Selenium in poultry nutrition and its effect on meat quality. World's Poult. Sci. J. 67:479-484.

Rashidi AA, Gofrani lvari Y, khatibjoo A and Vakili R (2010). Effects of dietary fat, vitamin E and zinc on immune response and blood parameters of broiler reared under heat stress. Research Journal of Poultry Sciences, 3: 32-38.

Reddy LS, Thangavel A, Leela V and Raju KV (2009). Antioxidant enzyme status in broilers: role of dietary supplementation of Tulasi (Ocimum sanctum) and selenium. Tamilnadu Journal of Veterinary and Animal Sciences, 5: 251-256.

Sahin N, Onderci M, Sahin K 2001. Effects of dietary chromium and zinc on egg production, egg quality and some blood metabolites of laying hens reared under low ambient temperature. Biol Trace Elem Resc (MMI-060).

Sahin, K. and O. Kucuk (2001). Effects of vitamin C and vitamin E on performance, digestion of nutrients, and carcass characteristics of Japanese quails reared under chronic heat stress $\left(34^{\circ} \mathrm{C}\right)$. J. Anim. Physiol. Anim. Nutr., 85: 335-342.

Sahin, K. Sahin, N. Onderci, M. Gursu M. F. and Issi, M.(2003). Vitamin C and E Can Alleviate Negative Effects of Heat Stress in Japanese Quails. Food, Agriculture and Envi- ronment, Vol. 1, No. 2, pp. 244249.

Sahin, K., N. Sahin and O. Kucuka, 2003. Effects of chromium, and ascorbic acid supplementation on growth, carcass traits, serum metabolites, and antioxidant status of broiler chickens reared at a high ambient temperature. Nutr. Res., 23: 225-238.

Sahin, K., N. Sahin, M. Onderci, F. Gursu and G. Cikim, 2002. Optimal dietary concentration of chromium for alleviating the effect of heat stress on growth, carcass qualities and some serum metabolites of broiler chickens. Biol. Trace Elet. Res., 89: 53-64.

Sahin, K.; Kücük, O.; Sahin, N. and Sari, M. (2002). Effects of vitamin C and vitamin E on lipid peroxidation status, serum hormone, metabolite, and mineral concentrations of Japanese. Quails reared under heat stress. (34 degrees C). Int J. Vit. Nutr.Res.,72: 91-100.

Sahin, N., K. Sahin, M. Onderci, M.F. Gursu, G. Cikim, J. Vijaya and O. Kucuk, 2005. Chromium picolinate, rather than biotin, alleviates performance and metabolic parameters in heat-stressed quail. $\mathrm{Br}$. Poult. Sci., 46: 457-463.

Sahin, N.; Onderci, M.; Sahin, K. and Kucuk, O. (2008). Supplementation with organic or inorganic selenium in heat-distressed quail. Biological Trace Element Research 122:229-237.

SAS (1996). SAS/STAT®User's Guide: Statistics Ver. 6.04, 4th ed. SAS Institute Inc., Cary, NC

Ševčíková, S.; Skrivan, M.; Dlouha, G. and Koucky, M. 2006. The effect of selenium source on the performance and meat quality of broiler chickens. Czech J. Anim. Sci. 51: 449-457.

Shlig A. A., (2009). Effect of vitamin E and selenium supplement in reducing aflatoxicosis on performance and blood parameters in broiler chicks. Iraqi Journal of Veterinary Sciences., 23: 97-103. 
Skřivan, M., M. Marounek, G. Dlouhá, and S. Ševčíková. (2008). Dietary selenium increases vitamin E contents of egg yolk and chicken meat. Br. Poult. Sci. 49:482- 486.

Spears, J. W.; Grimes, J.; Lloyd, K. and Ward, T. L. 2003. Efficacy of a novel organic selenium compound (zinc-L-selenomethionine, availaSe) in broiler chicks. 1st Latin American Congress of Animal Nutrition, Cancun: 197-198.

Sujatha, V. J. P. Korde, S. K. Rastogi, S. Maini, K. Ravi- kanth and D. S. Rekhe, 2010. Amelioration of Heat Stress In- duced Disturbances of the Antioxidant Defence System in Broilers. Journal of Veterinary Medicine and Animal Health, Vol. 2, No. 3, pp. 18-28.

Surai, P. F. (2006). Selenium in nutrition and health. Nottingham University Press, Nottingham, United Kingdom.

Surai, P. F. 2000. Effect of selenium and vitamin E content of the maternal diet on the antioxidant system of the yolk and the developing chick. Br. Poult. Sci. 41:235- 243.

Surai, P. F. 2000. Effect of selenium and vitamin E content of the maternal diet on the antioxidant system of the yolk and the developing chick. Br. Poult. Sci. 41:235- 243.

Surai, P.F., 2002. Selenium in poultry nutrition 1. Antioxidant properties, deficiency and toxicity. World's Poult. Sci. J. 58:333- 346.

Tietz, N. W. 1990. Clinical guide to laboratory tests. 2th Ed. Philadelphila: WB, Saunders; 566.

Toghyani, M., M. Shivazad, A.A.Gheisari and S.H. Zarkesh, (2006). Performance, carcass traits and heamatological parameters of heat stressed broiler chicks in response to dietary levels of chromium picolinate. Int. J. Poult. Scii. 5 (1): 65-69.

TRAS, B. F.; Inal, A.L.; Bas, V.; Altunok, M.; Elmas and Yazar E. (2000). Effects of continuous supplementations of ascorbic acid, aspirin,vitamin $\mathrm{E}$ and selenium on some haematological parameters and serum superoxide dismutase level in broiler chickens. British Poultry Science. 41: 664-666.

Utterback, P. L.; Parsons, C. M.; Yoon, I. and Butler, J. 2005. Effect of supplementing selenium yeast in diets of laying hens on egg selenium content, Poult. Sci., 84: 1900-1901.

Uyanik, F., A. Atasever, S. Ozdamar, and F. Aydin, 2002. Effect of dietary chromium chloride supplementation on performance, some serum parameters and immune response in broilers. Biol. Trace Elem. Res., 90: 99-115.

Ward, T. L., L. L. Southern, and S. L. Boleman. 1993. Effect of dietary chromium picolinate on growth, nitrogen balance and body composition of growing broiler chicks. J. Anim. Sci. 73 (Suppl.1):37. (Abstr.)

Wilson, W.O., 1971. Evaluation of stressor agents in domestic animals. J. Anim. Sci., 32: 578-583.

Wolf, G. 2005. The discovery of the antioxidant functions of vitamin E: the contribution of Henry A. Mattill. J. Nutr. 135:363-366.

Wolffram, S., 1999. Absorption and metabolism of Selenium: difference between organic and inorganic sources. In: Biotechnology in the Feed Industry. Lyons,T.P. and K.A. Jacques, ed. Nottingham University Press, Nottingham NG11 0AX, United Kingdom. Proc. 15th Annual Symposium, 15:547-566.

Yahav S. (1999): The effect of constant and diurnal cyclic temperatures on performance and blood system of young turkeys. J. Thermal. Biol., 24, 71-78.

Yahav S., Straschnow A., Plavnik I., Hurwitz S. (1997): Blood system response of chickens to changes in environmental temperature. Poultry Sci., 76, 627-633.

Yamaguchy S., 1991. The Role of SOD an Antioxidant, Jour- nal of National Cancer Institute, Vol. 28, No. 3, , pp. 221-232.

Yang, Y. R.; Meng, F. C.; Wang, P.; Jiang, Y. B.; Yin, Q. Q.; Chang, J.; Zuo1, R. Y.; Zheng, Q. H. and Liu, J. X. (2012) Effect of organic and inorganic selenium supplementation on growth performance, meat quality and antioxidant property of broilers. African Journal of Biotechnology Vol. 11(12), pp. 30313036. 


\section{Gouda et al.}

Yardibi H. and G. Turkay, 2008. The Effects of Vitamin E on the Antioxidant System, Egg Production, and Egg Quality in Heat Stressed Laying Hens. Turkish Journal of Vet- erinary and Animal Science, Vol. 32, No. 5, pp. 319-325.

Yardibi, H. and Turkay, G. (2008). The effects of vitaminE on theantioxidant system, egg production and egg quality in heat stressed laying hen.Turk.J.Vet. Anim. Sci. 32, 319-325. S. Pamoketal./ Journal of Thermal Biology 34(2009)353-357 357.

Zhou, X. and Wang, Y. 2011. Influence of dietary nano elemental selenium on growth performance, tissue selenium distribution, meat quality, and glutathione peroxidase activity in Guangxi Yellow chicken. Poult. Sci. 90:680-686.

Zulkifli, I., N. Abullah, N. Mohd and Y.W. Ho, 2000. Growth performance and immune response of two commercial broiler strains fed diets containing Lactobacillus cultures and oxytetracycline under heat stress conditions. Br. Poult. Sci., 41: 593-597.

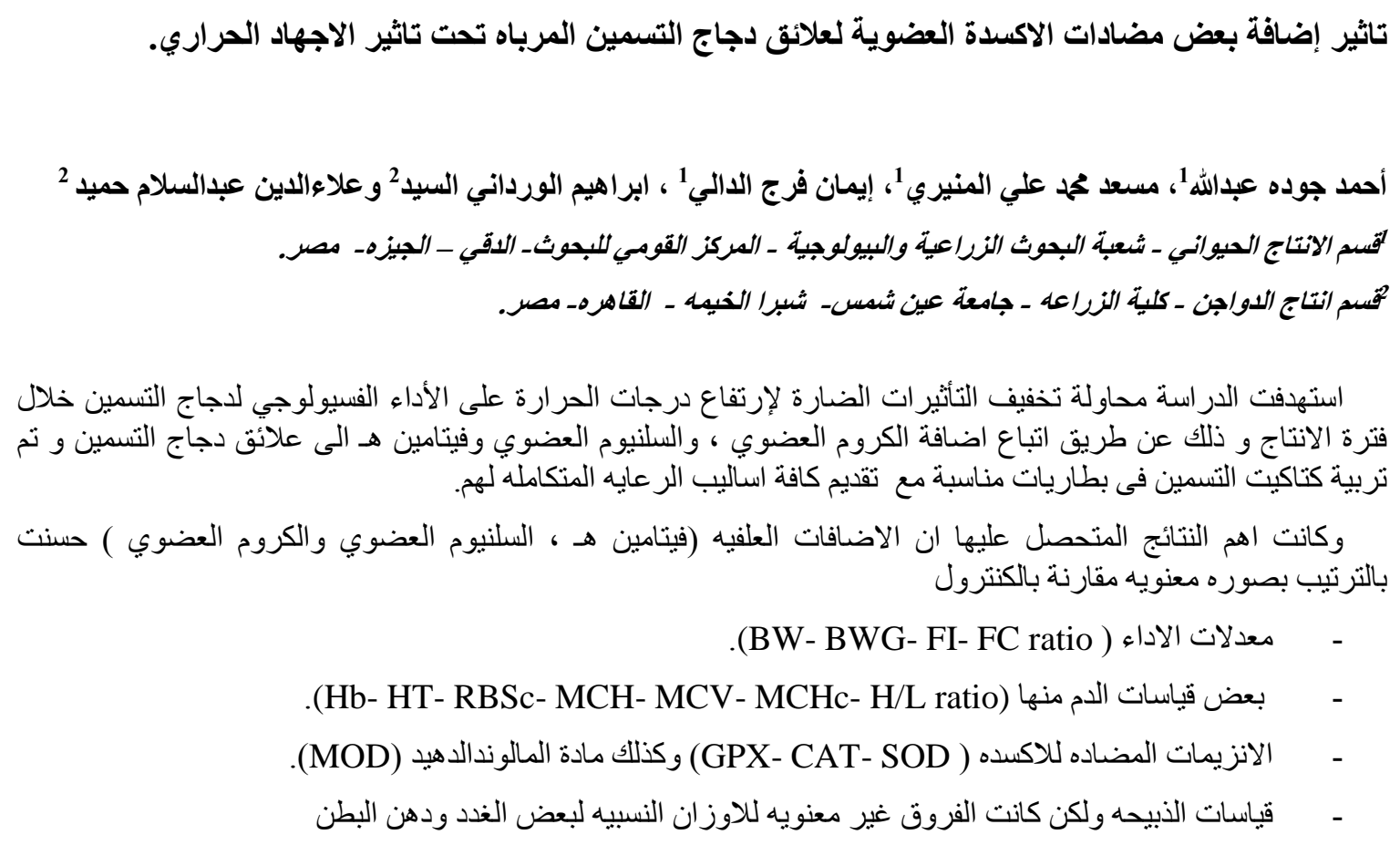

